\title{
Criminological and Criminal Classification of Crimes Connected with Trafficking in Persons in the Republic of Kazakhstan
}

\author{
Alimzhan Baurzhanovich Bekmagambetov \\ Kostanay Branch of Chelyabinsk State University (Kazakhstan), \\ Russian Peoples' Friendship University, doctoral studies \\ adilet1979@mail.ru
}

\begin{abstract}
In a scientific message based on the analysis of current criminal legislation, the vast empirical material Commission on Human Rights under the President of the Republic of Kazakhstan, the Prosecutor General, the Supreme Court, the Ministry of Internal Affairs of Kazakhstan and special literature on criminology and criminal legal classification, shows the efficiency of the use of the phrase "crime (crime), connected (associated) with trafficking in persons".

Through the prism of logical framework and comparative analysis of the Criminal Code of norms are accentuated similarities in complex phenomenon of trafficking in persons with such multifaceted criminal phenomena as terrorism, extremism, corruption, for which criminal law and criminology developed and legislator fixed lists of terrorist, extremist, corruption crimes.

In the article, expressing support for a proposal to return to the Criminal Code of the phrase "crimes, connected with trafficking in persons", it is considered necessary to supplement this list of existing rules on liability for illegal activities on adoption (adoption), human cloning, illegal removal of organs and human cadaver tissue, as well as novellas about the enslavement and the use of slave labour.

Keywords: criminological classification, classification of criminal law, crimes connected with trafficking in persons.

The area of the problem of counteraction to trafficking in persons in legal doctrine identified in the title of this publication has not been studied enough. Although such categories as "crimes (criminality) connected with trafficking in persons" are used actively
\end{abstract}


and efficiently in the practical activities of international organisations, law enforcement bodies, representatives of the non-governmental sector. It is fair to point that the issue of optimal terminology has been addressed in terms of the productivity of an integrative interdisciplinary approach $[3,4,5]$.

In this regard, the role and importance of the criminological and criminal classification of socially dangerous acts in such a complex sphere as trafficking in persons is evident.

The above-mentioned issues have been thoroughly studied and worked out in criminology.

As A. I. Dolgova points out "the groups of criminal acts that proceed from the socalled sign-manifestations and also have the specificity of self-determination are often considered during the distinguishing of the types of crimes as the complex of particular crimes" $[12,530]$.

A key feature in identifying of a group of crimes related to the trafficking in persons is, in our view, a focus on the criminal exploitation of the victim. The core of such commonality is trafficking in persons that correlates with all other acts thus being predicate (preceded) or concomitant (linked). In one of the more modern works V. V. Luneev writes: "The criminal systematisation of acts carried out according to the object of crime has a certain theoretical, practical and, to some extent, political significance" [13, 165]. According to this statement, it has a criminological meaning in terms of defining of a workload on the operational and investigative apparatus of various divisions, the prosecutor's office and courts for further monitoring of the effectiveness of registration activities, law enforcement practices, and law enforcement policy in general. Ultimately, everything is taken into account in the process of legislation improvement and departmental norm-setting.

In the Concept of Legal Policy of the Republic of Kazakhstan for the period between 2010-2020, it is particularly stated that "under the conditions of globalisation and the growth of world competition, many countries have faced the necessity of modernisation of legal systems and their maximal approach to the needs of people" [10].

The modernisation of the criminal legislation: the Criminal Code, the Criminal Procedure Code, and the Correctional Code, was one of the priority measures that received positive scientific and expert feedback.

In collaboration with the interested state bodies, the General Prosecutor's Office of the Republic of Kazakhstan developed the State Programme for Further Modernisation of the Law Enforcement System of the Republic of Kazakhstan for 2014-2020, approved by the Decree of the President of the Republic of Kazakhstan No. 720 of 31 December 2013.

An implementation of the Programme together with the Concept on Kazakhstan's entry into the list of 30 most developed states of the world, approved by the Presidential Decree No. 732 of 17 January 2014, will create the basis for a reliable law enforcement 
system that will meet the world standards, in which human rights will be the starting point and take a key place. At the same time, "the main indicator of this work is the level of citizens' trust in law enforcement agencies" [21, 2].

The system of measures to counter trafficking in persons is steadily developing today as part of the aforementioned large-scale work on reformatting and modernisation of the legal policy of the Republic of Kazakhstan, including law enforcement activity. Simultaneously, the opinion of L. Golovko proves relevant: "In general, the reform of bodies conducting "the crime fighting" will be effective only if it is carried out on the basis of a unified understanding of a "law violation that deserves the use of state repression" (substantive level), "police inquiry (investigation)" (procedural level) and "police" (institutional level)" [9, 43].

A serious breakthrough has been made in strengthening of interdepartmental and international cooperation in counteraction to criminal challenges and threats, including trafficking in persons in Kazakhstan at the present stage. The country has joined a number of essential Conventions in the field of fundamental all humanities values, rights and freedoms of human and citizen, also a number of multilateral and bilateral agreements have been concluded in the field of counteraction to trafficking in persons.

The Interdepartmental Commission on issues of counteraction to illegal export, import and trafficking in persons under the Government of the Republic of Kazakhstan performs comprehensive and systematic activities today. It includes the Agency of the Republic of Kazakhstan for Civil Service Affairs and Anti-Corruption, the Supreme Court of the Republic of Kazakhstan, General Prosecutor's Office of the Republic of Kazakhstan, the National Security Committee of the Republic of Kazakhstan, the Commission on the Human Rights under the President of the Republic of Kazakhstan, the Ministry of Internal Affairs of the Republic of Kazakhstan, the Ministry of Health of the Republic of Kazakhstan, the Ministry of Foreign Affairs of the Republic of Kazakhstan, the Ministry for Investment and Development of the Republic of Kazakhstan, the Ministry of Culture and Sports of the Republic of Kazakhstan, the Ministry of Education and Science of the Republic of Kazakhstan, the Ministry of Labour and Social Protection of the Republic of Kazakhstan, the Ministry of Finance of the Republic of Kazakhstan, the Ministry of Justice of the Republic of Kazakhstan, the National Centre for Human Rights [18].

They jointly participate in the norm-setting on the improvement and harmonisation of legislation, in the implementation of organisational and practical measures to counter trafficking in persons and assist victims, in cooperation with the competent authorities of the CIS member states, as well as with the international and non-governmental organisations. A special place among the areas of joint work belongs to the implementation of organisational and preventive measures against trafficking in persons. Informational, scientific and methodological, and personnel support is specially provided in order to create the necessary conditions for the stated types of work. 
As a result of such integrated approach, the extensive experience has been accumulated in the sphere of legal and regulatory framework improving, law enforcement practice has been formed, the reciprocal connection between interested state bodies and civil society institutions has been established for over a 20 -year period to improve the effectiveness of counteraction to crimes related to trafficking in persons.

The constant monitoring of the dynamics of crime development related to trafficking in persons and its reflection in relevant analytical materials of the Commission on the Human Rights under the President of the Republic of Kazakhstan, the General Prosecutor's Office, the Supreme Court, and the Ministry of Internal Affairs of the Republic of Kazakhstan is rank among the primary measures. It should be noted that similar work is carried out by international and domestic non-governmental organisations.

Prior to 2013, the criminal classification of acts related to trafficking in persons included only two types of crime: trafficking in persons and trafficking in minors.

Specialists state that "according to the statistical data of the Committee on Legal Statistics and Special Records of the General Prosecutor's Office of the Republic of Kazakhstan, the growth of the crimes in question is marked" (in accordance with Article 128 "Trafficking in Persons", Article 133 of the Criminal Code of the Republic of Kazakhstan "Trafficking in Minors") [11, 170]. The number of initiated criminal cases has been provided in Table 1.

According to Non-governmental organizations (NGOs), the number of initiated criminal cases related to trafficking in persons has increased significantly in recent years. According to the Ministry of Internal Affairs of the Republic of Kazakhstan, 271 criminal cases were initiated on facts connected with trafficking in persons in the country in 2009, including 20 criminal cases under Article 128 of the Criminal Code of the Republic of Kazakhstan ("Trafficking in Persons"), 16 criminal cases under Article 133 ("Trafficking in Minors"); 18 criminal cases under Article 128 of the Criminal Code of the Republic of Kazakhstan ("Trafficking in Persons") and 10 criminal cases under Article 133 ("Trafficking in Minors") were initiated by the police during the first half of 2010 [2, 9].

Table 1. The number of initiated crime cases in trafficking in persons

\begin{tabular}{|c|c|c|}
\hline \multirow{2}{*}{ Year } & \multicolumn{2}{|c|}{ Criminal Code of the Republic of Kazakhstan } \\
\cline { 2 - 3 } & Article 128 & Article 133 \\
\hline 2004 & 15 & 0 \\
\hline 2005 & 13 & 4 \\
\hline 2006 & 20 & 5 \\
\hline 2007 & 19 & 5 \\
\hline 2008 & 17 & 8 \\
\hline 7 months of 2009 & 19 & 1 \\
\hline
\end{tabular}


Alimzhan Baurzhanovich Bekmagambetov. Criminological and Criminal Classification of Crimes Connected with Trafficking in Persons in the Republic of Kazakhstan

The report submitted to the United Nations Committee on the Elimination of Discrimination against Women contains the following information:

- 16 crimes were registered on the territory of the Republic of Kazakhstan in 2006 (under Article 128 of the Criminal Code of the Republic of Kazakhstan "Trafficking in Persons" and Article 133 of the Criminal Code of the Republic of Kazakhstan "Trafficking in Minors" - the Author's comment), which is $77.8 \%$ more than in 2005 (9);

- 18 criminal cases concerning trafficking in persons (Article 128 of the Criminal Code) and 6 cases related to trafficking in minors (Article 133 of the Criminal Code) were in the proceedings in the criminal investigation bodies in 2007;

- the number of crimes related to trafficking in persons increased and amounted to 44 crimes in 2008 ;

- 229 criminal cases were initiated on facts connected with trafficking in persons in 2009;

- 193 criminal cases were considered by the courts of the Republic at first instance for 12 months of 2010 [6, 22]. Paragraph 4 "crimes related to trafficking in persons shall be recognised as crimes provided for by Article 113, paragraph 113, paragraph (b) of part 3 of Article 125, paragraph (b) of part 3 of Article 126, Articles 128, 132-1, 133, 270 and 271 of this Code" was added by the Law of the Republic of Kazakhstan "On Amendments and Additions to Certain Legislative Acts of the Republic of Kazakhstan on Counteraction Trafficking in Persons" No. 127-V of 4 July 2013, in the footnote to Article 128 of the Criminal Code of the Republic of Kazakhstan "Trafficking in Persons" [22].

At the end of the same year, the Committee on Legal Statistics and Special Records of the General Prosecutor's Office published the first statistical data, according to which 501 crimes related to trafficking in persons were registered in 2010, 584 - in 2011, 505 in 2012, 468 - during 11 months of 2012, 752 - during 11 months of 2013 [1, 1].

However, referring to Table 2 of the special report of the Commission on the Human Rights under the President of the Republic of Kazakhstan, different numbers are represented: 285 crimes related to trafficking in persons were registered in 2011, 267 - in 2012, 350 - in 2013 [19, 25].

The Report on the Implementation of International Standards in the Sphere of Human and Civil Rights and Freedoms states that 900 criminal cases were instituted between 2011-2013, including 38 concerning the abduction of a human for the purpose of exploitation, 35 - illegal imprisonment with the intention to exploit, 77 - trafficking in persons, 30 - involvement in prostitution, 47 - trafficking in minors, 89 - involvement in prostitution, 584 - establishment and upkeep of a brothel for the purposes of prostitution and procuring $[23,12]$.

With the reference to the Criminal Police Committee of the Ministry of Internal Affairs of the Republic of Kazakhstan the International Organisation for Migration in Kazakhstan notes that the number of criminal cases for this type of crime was 2,987 between 2004 and $2013[4,7]$. 
Alimzhan Baurzhanovich Bekmagambetov. Criminological and Criminal Classification of Crimes Connected with Trafficking in Persons in the Republic of Kazakhstan

Table 2. Information on criminal cases on the facts of human abduction, illegal imprisonment and trafficking in persons sent to court between 2009-2013 [15, 4]

\begin{tabular}{|c|c|c|c|}
\hline \multirow{2}{*}{ Year } & \multicolumn{3}{|c|}{ Criminal Code of the Republic of Kazakhstan } \\
\cline { 2 - 4 } & Article 125 & Article 126 & Article 128 \\
\hline 2009 & 72 & 0 & 5 \\
\hline 2010 & 69 & 97 & 15 \\
\hline 2011 & 72 & 92 & 20 \\
\hline 2012 & 61 & 17 & 7 \\
\hline 2013 & 65 & 105 & 21 \\
\hline
\end{tabular}

In comparative terms, we note that in accordance with the same document, there were 279 criminal cases of this kind in 2010, 287 - in 2011, 267 - in 2012, 348 - in 2013. The latest data practically coincide with the figures of another document that reflects that 346 criminal cases were initiated in 2013 [24, 10].

In addition, we should note that according to the General prosecutor's Office of the Republic of Kazakhstan " 88 crimes in the sphere of trafficking in minors were committed in 2013" [14, 5].

According to the Ministry of Internal Affairs of the Republic of Kazakhstan, 776 criminal cases related to trafficking in persons were in the proceedings in internal affairs agencies during 11 months of 2016 in comparison with 695 of the same period of the previous year (the increase of $11.6 \%$ ) [20,1].

This category includes the criminal offenses provided for by the:

- Article 116 of the Criminal Code (forced removal or illegal removal of human organs or tissues);

- Article 125 part $3 \$ 2$ of the Criminal Code (abduction of a human for the purpose of exploitation);

- Article 126 part $3 \$ 2$ of the Criminal Code (illegal imprisonment with the intention to exploit);

- Article 128 of the Criminal Code (trafficking in persons);

- Article 134 of the Criminal Code (the involvement of the minor in prostitution);

- Article 135 of the Criminal Code (trafficking in minors);

- Article 308 of the Criminal Code (the involvement in prostitution);

- Article 309 of the Criminal Code (establishment and upkeep of a brothel for the purposes of prostitution).

In the context of the previously mentioned Criminal Law norms, the state of things is as follows:

- two criminal cases under Article 116 of the Criminal Code (forced removal or illegal removal of human organs or tissues) were in proceedings (Departments of Internal Affairs of Almaty and Astana cities); 
- six criminal cases under Article 125 part $3, \$ 2$ of the Criminal Code (abduction of a human for the purpose of exploitation) were in the proceedings (Departments of Internal Affairs of South Kazakhstan region - 3; Aktobe region - 2; East Kazakhstan region -1) including four cases sent to court compared with only two cases during the same period of time a year before;

- 32 criminal cases under Article 126 part 3, $\$ 2$ of the Criminal Code (illegal imprisonment with the intention to exploit) were in proceedings (Departments of Internal Affairs of Almaty - 12; Karaganda region - 8; South Kazakhstan region - 7; Astana city, Aktobe, Atyrau regions - 1 in each; central apparatus of the Ministry of Internal Affairs - 1); 19 criminal cases were in the proceedings during the same period compared to previous year. In total, 23 criminal cases were sent to court;

- 102 criminal cases under Article 128 of the Criminal Code (trafficking in persons) were in the proceedings (Departments of Internal Affairs of Kostanay region - 20 criminal cases; Karaganda region - 18; East Kazakhstan region - 14; Aktobe region - 7; Astana city and Akmola region - 6 in each; Jambyl, South and North Kazakhstan regions - 5 in each; Almaty city - 4; Almaty, West Kazakhstan and Kyzylorda regions - 3 in each; Mangystau region - 2; Atyrau region - 1) in comparison with 84 criminal cases a year before. 23 of the above-mentioned criminal cases were sent to court $(2-$ in 2015);

- 31 criminal cases under Article $\mathbf{1 3 4}$ of the Criminal Code (the involvement of the minor in prostitution) were in the proceedings (Departments of Internal Affairs of Astana city, Almaty city, Akmola and West Kazakhstan regions 4 in each; North Kazakhstan region - 3; East Kazakhstan, Jambyl, Karaganda and Kostanay regions - 2 in each; Aktobe, Kyzylorda, Mangystau and South Kazakhstan regions - 1 in each) in comparison with 28 criminal cases of 2015. Only two cases were sent to court;

- 47 criminal cases under Article 135 of the Criminal Code (trafficking in minors) were in the proceedings (Departments of Internal Affairs of Almaty city - 18; Mangystau region - 6; Astana city, Atyrau and Karaganda regions - 4 in each; South Kazakhstan and Almaty regions - 3 in each; Akmola, Aktobe, Kostanay, Kyzylorda, North Kazakhstan regions and on transport - 1 in each) in comparison with 39 of the previous year. 25 cases were sent to court;

- 105 criminal cases under Article 308 of the Criminal Code (the involvement in prostitution) were in the proceedings (Departments of Internal Affairs of Almaty city - 35; Astana city - 18; Akmola region - 12; Kyzylorda region - 7; Almaty and South Kazakhstan regions - 6 in each; West Kazakhstan - 5; Karaganda, Pavlodar and North Kazakhstan regions - 3 in each; Atyrau region - 2; Aktobe, East Kazakhstan, Jambyl, Kostanay regions and the Representation of the Ministry of Internal Affairs of Baikonyr city - 1 in each) in comparison with 103 cases of the same period of a year prior. 6 cases were sent to court in 2016; 
- 451 criminal cases under Article 309 of the Criminal Code (establishment and upkeep of a brothel for the purposes of prostitution and procuring) were in the proceedings (Departments of Internal Affairs of Astana city - 57; Almaty city - 55; South Kazakhstan region - 51; Karaganda region - 44; Almaty region - 40; East Kazakhstan region - 32; Akmola region - 24; West Kazakhstan region - 23; Kyzylorda region - 20; Jambyl region - 19; Kostanay region - 18; Mangystau region - 16; North Kazakhstan region - 13; Aktobe region - 11; on transport - 10; Pavlodar region - 9; Atyrau region - 7; in the Representation of the Ministry of Internal Affairs in Baikonyr city and the Central apparatus 1 in each) in comparison with 419 cases in 2015.99 cases were sent to court. The criminological classification of acts connected with trafficking in persons is actively used is investigatory practice. Compositions of this group are distributed among different chapters of the Special part of the Criminal Code of the Republic of Kazakhstan and respectively have different objects of infringement.

As stated in $\$ 2$ of the regulatory decree of the Supreme Court of the Republic of Kazakhstan No. 7 of 29 December 2012 "On the practice of the application of legislation which introduces responsibility for trafficking in persons', the objects of crime connected with the trafficking in persons are human freedom, security, rights and legitimate interests, honour and dignity, freedom to choose the place of residence, type of activity and occupation" [7,22]. Currently, according to the new Criminal Code of the Republic of Kazakhstan, the regulatory decrees of the Supreme Court along with the Constitutional Council are constitutive parts of the current Criminal Law.

Simultaneously, when a new Criminal Code of the Republic of Kazakhstan came in force in 2015, during the integration of practice the Supreme Court of the Republic of Kazakhstan relied on the formulation "crimes connected with the trafficking in persons", excluded by the legislator. Particularly, it was noted that

“... in the notes to Article 128 of the Criminal Code of the earlier version the legislator explains the concepts of buying and selling, other deals concerning trafficking in persons, the consent of victim, the list of crimes connected with trafficking in persons is given in: Article 113 of the Criminal Code - forced removal or illegal removal of human organs or tissues; Article 125 part 3 paragraph (b) of the Criminal Code - abduction of a human for the purpose of exploitation; Article 126 part 3 paragraph b) of the Criminal Code - imprisonment with the intention to exploit; Article 128 of the Criminal Code trafficking in persons; Article 132-1 of the Criminal Code - the involvement of the minor in prostitution; Article 133 of the Criminal Code - trafficking in minors; Article 270 of the Criminal Code - the involvement in prostitution; Article 271 of the Criminal Code - establishment and upkeep of a brothel for the purposes of prostitution and procuring" $[16,39]$.

As follows from the analytical document of the Supreme Court of the Republic of Kazakhstan, 208 criminal cases (209 cases - in 2013) were sent to court in 2014, including 166 cases or $79.8 \%$ (163 or $78 \%$ - in 2013) under Article 271 of the Criminal 
Alimzhan Baurzhanovich Bekmagambetov. Criminological and Criminal Classification of Crimes Connected with Trafficking in Persons in the Republic of Kazakhstan

Code (establishment and upkeep of a brothel for the purposes of prostitution and procuring), 20 cases or $9.6 \%$ (17 cases or $8.1 \%$ - in 2013) under Article 133 of the Criminal Code (trafficking in minors), 8 cases or $3.8 \%$ (6 cases or $2.9 \%$ - in 2013) under Article 128 of the Criminal Code (trafficking in persons), 7 cases or 3.4\% (9 cases or 4.3\% - in 2013) under Article 126 part 3 of the Criminal Code (illegal imprisonment), 3 cases or 1.4\% (6 cases or 2.9\% - in 2013) under Article 125 part 3 of the Criminal Code (abduction of a human), 2 cases or $0.9 \%$ ( 5 cases or $2.4 \%$ under Article 270 of the Criminal Code, 3 cases or 1.4\% under Article 132-1 of the Criminal Code - in 2013) under each Articles 270 and 132-1 of the Criminal Code (the involvement in prostitution/the involvement of the minor in prostitution).

In total 199 criminal cases (191 cases - in 2013) were concluded in 2014, including 159 cases with the delivery of the judgement (153 cases - in 2013). The greatest number of cases was concluded by courts of Astana city (45), Almaty city (22), East Kazakhstan (21) and South Kazakhstan (20) regions. The least number of criminal cases was concluded by courts of Mangystau and Pavlodar regions ( 2 in each). The number of criminal cases concerning establishment and upkeep of a brothel for the purposes of prostitution and procuring has been prevailing (about 70\%) in the criminal sphere connected with trafficking in persons since 2008. 185 people were convicted in 2014 (175 - in 2013) including 40 people or $21.6 \%$ (42 people or $24 \%$-in 2013) of the total number were sentenced to imprisonment, 140 people or $75.7 \%$ (113 or 64.6\% - in 2013) were given a suspended sentence.

In the context of Articles of the Criminal Code, 133 people or $71.9 \%$ (127 people or $72.6 \%$ - in 2013) were convicted under Article 271 of the Criminal Code, 29 people or $15.7 \%$ (16 people or 9.1\% - in 2013) - under Article 133 of the Criminal Code, 8 people or 4.3\% (6 people or 3.4\% - in 2013) - under Article 128 of the Criminal Code, 5 people or 2.7\% (12 people or $6.8 \%$ - in 2013) - under Article 126 part 3 of the Criminal Code, 5 people or 2.7\% (8 people or 4.6\% - in 2013) - under Article 125 part 3 of the Criminal Code, 4 people or $2.1 \%$ (4 people or $2.3 \%$ - in 2013) - under Article 270 of the Criminal Code, 1 person or $0.5 \%$ ( 2 people or $1.1 \%$ - in 2013) - under Article 132-1 of the Criminal Code. Overall, generalisation of court practice was devoted to questions of the right qualification, assignment of punishment, i.e., criminal aspects of counteraction to the mentioned category of criminal actions. Globally, the primary emphasis was placed upon the criminal subsystem in above-mentioned analytical document in the context of political conception and connected with the counteraction to trafficking in persons. Consecutively, the Supreme Court of the Republic of Kazakhstan issued the generalisation on the questions of protection the victims' rights in cases of trafficking in persons during the trial in 2016 (based on criminal cases considered in 2014-2015) in the light of actively following the course of strengthening of law enforcement effectiveness by emphasising victimisation policy [15]. 
In total, 160 of 208 criminal cases received in 2014 were concluded, 182 people were convicted; 109 of 158 criminal cases were concluded and 109 people were convicted in 2015. The greatest number of all criminal actions traditionally were represented under Article 270 of the Criminal Code; 160 criminal cases were considered according to this norm and 182 people were convicted in 2014; there were respectively 109 cases and 117 convicts in 2015. Two interconnected elements of policy of counteraction to criminality connected with trafficking in persons were noticed in the above-mentioned official document: criminal procedure and criminological subsystems. Nevertheless, in regards to legal classification of crimes connected with the trafficking in persons, theoretical and applied significance of the formulation "crimes connected with the trafficking in persons" should be recognised that, in turn, reveals a complicated multisided character of this phenomenon that is identical to organised criminality, terrorism, extremism and corruption. The legislator established criminologically founded lists of terroristic, extremist, corruption crimes in the Criminal Code of the Republic of Kazakhstan with regard to them. On a larger scale all these multifaceted phenomena can hardly be put in the frame and taxonomy of Criminal Law in the sense of definition of the term and systematisation of actions; therefore, the role of criminological science is growing. The importance of the Criminal Law doctrine is not depreciated, and the integrative model of the interaction between criminology and Criminal Law is optimal and efficient.

The legislator has undeservingly excluded the corresponding list during the regular full-scale modernisation of the Criminal Code of the Republic of Kazakhstan. In this regard the judiciary representatives of the country are fairly pointing at the necessity of return of pre-existing and practically demanded formulation in the aforementioned generalisation that included the individual norm in Article 3 of the Criminal Code of the Republic of Kazakhstan.

In support of this position, the list must include Criminal Law norms of responsibility for illegal adoption, human cloning, illegal removal of human corpse organs or tissues, slavery and the use of slave labour. It is fair to point that there is still no any Article on slavery in the current Criminal Code that is the significant legal gap. The following title of the normative decree by the Supreme Court of the Republic of Kazakhstan No. 7 of 29 December 2012 "On practice of usage of legislation establishing responsibility for crimes connected with trafficking in persons" appears to be justified for the further harmonisation of the juridical system.

As for the global approach, it is rational to pass a main law on counteraction to criminality connected with trafficking in persons that is a legal basis of the corresponding type of anti-criminal policy. 


\section{Ar cilvēku tirdzniecību saistīto noziegumu kriminoloǵiskā un krimināltiesiskā klasifikācija Kazahstānas Republikā}

\section{Kopsavilkums}

Zinātniskā izpēte parāda frāzes "noziegums (noziedzība), kas saistīts ar cilvēku tirdzniecību", izmantošanas efektivitāti, un tā ir balstīta uz spēkā esošo krimināltiesību aktu analīzi, uz Kazahstānas Republikas prezidenta pakḷautībā esošās komisijas cilvēktiesību jautājumos, generālprokurora, Augstākās tiesas, Kazahstānas Iekšlietu ministrijas plašu empīrisko materiālu izpēti un speciālo literatūru par kriminolog̣iju, kā arī krimināltiesisko klasifikāciju.

Caur Kriminālkodeksa normu prizmu logisko ietvaru un salīdzinošo analīzi tiek parādīta sarežgìitās parādības - cilvēku tirdzniecības - līdzība ar tādām daudzšḳautņainām noziedzīgām parādībām kā, piemēram, terorisms, ekstrēmisms, korupcija.

Autors, paužot atbalstu priekšlikumam atgriezties Kriminālkodeksā pie frāzes "noziegumi, kas saistīti ar cilvēku tirdzniecību", uzskata, ka ir nepieciešams papildināt spēkā esošo noteikumu sarakstu par atbildību par nelikumīgām darbībām saistībā ar adopciju (adopciju), cilvēka klonēšanu, nelegālu orgānu un cilvēka k̦ermeṇa audu izn,emšanu, kā arī par verdzību un vergu darbu.

Atslēgvārdi: kriminolog̣iskā klasifikācija, krimināltiesību klasifikācija, ar cilvēku tirdzniecību saistìti noziegumi.

\section{References}

1. Analiz statisticheskih dannyh o sostoyanii prestupnosti, svyazannoi s torgovlej lyudmi za 2010-2012 g.g., 11 mesyatsev 2013 goda. Astana: Komitet po pravovoj statistike i spetsialnym uchetam Generalnoj prokuratury RK, 4 dekabrya 2013 goda, 9 s. (Анализ статистических Аанных о состоянии преступности, связанной с торговмей АюАьми за 2010-2012 г.г., 11 месяцев 2013 года. Астана: Комитет по правовой статистике и специальным учетам Генеральной прокуратуры РК, 4 Аекабря 2013 года, 9 с.)

2. Analiz tekushchego polozheniya del v sfere bor'by s torgovlej lyud'mi v Kazahstane. Doklad k tret'jej sessii Obzornoj konferentsii OBSE 2010 goda, Astana, 26-28 noyabrya 2010 g. (Анализ текущего положения Аел в сфере борьбы с торговлей цюАьми в Казахстане. АокмаА к третьей сессии Обзорной конференции ОБСЕ 2010 гоАа, Астана, 26-28 ноября 2010 г.)

3. Bekmagambetov, A. B. O kategoriyah 'prestupleniya, svyazannye s torgovlej lyudmi' i 'prestupnost', svyazannaya s torgovlej lyudmi'i ih teoretiko-prikladnom znachenii. Prestupnost' $i$ sotsial'nyj kontrol'v obshchestve postmoderna: Sbornik materialov XXVIII Mezhdunarodnoj nauchnoj Baltijskoj kriminologicheskoj konferentsii. Ch. 1. Pod red. V. Yu. Smorgunovoj, Ya. I. Gilinskogo, N. A. Isaeva. Sankt-Peterburg: ID 'Alef-Press', 2015. 250 s. (Бекмагамбетов, А. Б. О категориях «преступления, связанные с торговмей ^юАьми» и «преступность, связанная с торговлей 
Alimzhan Baurzhanovich Bekmagambetov. Criminological and Criminal Classification of Crimes Connected with Trafficking in Persons in the Republic of Kazakhstan

Аюдьми» и их теоретико-прикладном значении. Престуиность и соииальный контроль в обществе постмодерна: Сборник материалов XXVIII Международной научной Балтийской криминологической конферениии. Ч. 1. ПоА реА. В. Ю. Сморгуновой, Я. И. Гилинского, Н. А. Исаева. Санкт-Петербург: ИА «Алеф-Пресс», 2015. 250 с.)

4. Bekmagambetov, A. B. O neraskrytom potentsiale kategorij 'prestupleniya, svyazannye s torgovlej lyud'mi' i 'prestupnost', svyazannaya s torgovlej lyud'mi'. Aktual'nye problemi teorii i praktiki protivodejstviya prestupnosti v sovremennoj Rossii: materialy II Mezhdunarodnoj nauchnoprakticheskoj konferenciy. Pod obshch. red. Yu. S. Zharikova i nauch. red. V. P. Revina. Moskva: Izd-vo SGU, 2015. 436 s. (Бекмагамбетов, А. Б. О не раскрытом потенциале категорий «преступмения, связанные с торговлей АюАьми» и «преступность, связанная с торговлей АюАьми». Актуальные проблемы теории и практики противодействия преступности в современной России: Материаль II Международной научно-практической конберениии. ПоА общ. реА. Ю. С. Жарикова и науч. реА. В. П. Ревина. Москва: ИзА-во СГУ, 2015. 436 с.) 5. Bekmagambetov, A. B. O sootnoshenii ponyatij 'prestupleniya, svyazannye s torgovlej lyud'mi' i 'prestupnost', svyazannaya s torgovlej lyud'mi'. Rossiya v XXI veke: ekonomicheskie, pravovye $i$ sotsial'no-kul'turnye perspektivy razvitiya. Materialy IX Mezhdunarodnoj nauchno-prakticheskoj konferentsii. Otv. red. M. P. Zhuravlev. Moskva: Izdatel'stvo: Rossijskij universitet druzhby narodov, 2016. 239 s. (Бекмагамбетов, А. Б. О соотношений понятий «преступ-

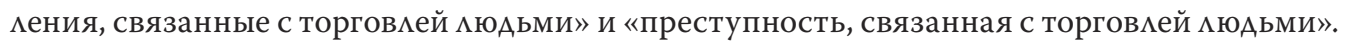
Россия в ХХІ веке: экономические, правовые и социально-культурные перспективы развития. Материалы IX Международной научно-практической конференции. Отв. реА. М. П. Журавлев. Москва: ИзАательство «Российский университет Аружбы народов», 2016. 239 c.)

6. Bor'ba s torgovlej lyud'mi: Kazahstan. Statisticheskie dannye s yanvarya 2004 - po iyun' 2014 goda. Astana: MOM v Kazahstane, 2014. 7 s. (Борьба с торговлей Аюдьми: Казахстан. Статистические данные с января 2004 по июнь 2014 года. Астана: МОМ в Казахстане, 2014. 7 с.)

7. Byulleten’ Verhovnogo Suda Respubliki Kazahstan. 2013. No. 1. (Бюлметень Верховного СуАа Республики Казахстан. 2013. № 1.)

8. Doklad o vypolnenii Konventsii o likvidatsii vseh form diskriminatsii v otnoshenii zhenshchin. Utverzhden postanovlenijem Pravitel'stva RK ot 15.09.2011 g. No. 1064. Astana, 2011. 63 s. (АоклаА о выполнении Конвенции о АиквиАации всех форм Аискриминации в отношении женщин. УтвержАен постановлением Правительства РК от 15.09.2011 г. № 1064. Астана, 2011.63 c.)

9. Golovko, L. Perspektivy reformirovaniya organov, osushchestvlyayushchih obespechenie bezopasnosti i bor'bu s prestupnost'yu. Zanhger, 2010, No. 9. (Головко, $\Lambda$. Перспективы реформирования органов, осуществцяющих обеспечение безопасности и борьбу с преступностью. Заңчгер, 2010, № 9.)

10. Kazahstanskaja Pravda. 27.08.2009. №. 205 (25949) (Казахстанская правда. 27.08.2009. № 205 (25949).)

11. Kenbaev, Zh. A., Ospanov, S. A. Teoreticheskie aspekty ugolovno-pravovogo regulirovaniya meropriyatij po protivodejstviyu torgovle lyud'mi v Respublike Kazahstan. Konstitutsiya Respubliki Kazahstan: 15 let: Materialy mezhdunarodnoi nauchno-prakticheskoj konferenciy. Karaganda: KarYuI MVD RK im. B. Bejsenova, 2009. T. 1. (Кенбаев, Ж. А., Оспанов, С. А. 
Alimzhan Baurzhanovich Bekmagambetov. Criminological and Criminal Classification of Crimes Connected with Trafficking in Persons in the Republic of Kazakhstan

Теоретические аспекты уголовно-правового регукирования мероприятий по противоАействию торговле мюАьми в Респубцике Казахстан. Конституция Республики Казахстан: 15 лет. Материалы Международной научно-практичческой конберениии. Отв. реА. С. Е. Еркенов, И. Ш. Борчашвили. Караганда: КарЮИ МВА РК им. Б. Бейсенова, 2009. T. 1.)

12. Kriminologija: uchebnik. Pod. obshch. red. A. I. Dolgovoj. 4-je izd., pererab. i dop. Moskva: Norma, Infra-M, 2010. 1008 s. (Криминология: учебник. ПоА общ. реА. А. И. Аолговой. 4-е изА., перераб. и доп. Москва: Норма, Инфра-М, 2010. 1008 с.)

13. Monitoring ugolovnoj politiki Rossii. Monografiya. Pod. obshch. red. S. V. Maksimova. Moskva: Institut gosudarstva i prava RAN, 2015. 482 s. (Мониторинг уголовной политики России. Монография. Под общ. реА. С. В. Максимова. Москва: Институт государства и права РАН, 2015.482 c.)

14. Ob itogah proverki primeneniya zakonodatel'stva ob usynovlenii za 2012-2013 gody. Astana: General'naya prokuratura RK, 2013. 28 s. (Об итогах проверки применения законодательства об усыновлении за 2012-2013 годы. Астана: Генеральная прокуратура РК, 2013. 28 с.)

15. Obobshchenie po voprosam o bespecheniya v sudebnom razbiratel'stve prav poterpevshih po delam o torgovle lyud'mi (na osnove rassmotrennyh v 2014-2015 g.g. ugolovnyh del). Byulleten' Verhovnogo Suda Respubliki Kazahstan. 2016, 12: 78-108. (Обобщение по вопросам обеспечения в судебном разбирательстве прав потерпевших по Аелам о торговле основе рассмотренных в 2014-2015 г.г. уголовных Аел). Бюллетень Верховного Суда Республики Казахстан. 2016, 12: 78-108.)

16. Obobshchenie sudebnoj praktiki po ugolovnym delam, svyazannym s torgovlej lyud'mi za 2013 i 2014 gody (predusmotrennymi stat'yami 125, ch. 3, p. 'b'; 126, ch. 3 p. 'b'; 128, 132-1, 270, 271 UK). Byulleten' Verhovnogo Suda Respubliki Kazahstan. 2015, 12: 36-64. (Обобщение судебной практики по уголовным делам, связанным с торговлей Аюдьми за 2013 и 2014 годы (преАусмотренными статьями 125, ч. 3, п. «б»; 126, ч. 3 п. «б»; 128, 132-1, 270, 271 УК). Бюллетень Верховного Суда Республики Казахстан. 2015, 12: 36-64.)

17. Pervyj periodicheskij doklad o merah, prinyatyh Respublikoj Kazahstan $v$ tselyah osushchestvleniya Mezhdunarodnoj konventsii dlya zashchity vseh lits ot nasil'stvennyh ischeznovenij. Utverzhden postanovleniem Pravitel'stva RK ot 27.05.2014 g. No. 547. Astana, 2014. 22 s. (Первыци периодическй доклад о мерах, принятых Республикой Казахстан в целях осуществления Международной конвенции для зашиты всех лии от насильственньх исчезновений. Утвержден постановлением Правительства РК от 27.05.2014 г. № 547. Астана, 2014. 22 с.)

18. Plan meropriyatij pravitel'stva Respubliki Kazahstan po profilaktike, predotvrashcheniyui bor'be s prestupleniyami, svyazannymi s torgovlej lyud'mi na 2015-2017 gody. Utverzhden postanovleniem Pravitel'stva Respubliki Kazahstan ot 28.01.2015 goda No. 23. (План мероприятий правительства Республики Казахстан по пробилактике, предотвращению и борьбе с преступлениями, связанными с торговлей людьми на 2015-2017 годы. Утвержден постановиением правительства Республики Казахстан от 28.01.2015 года № 23.)

19. Spetsial'nyj doklad 'Aktual'nye problem zashchity prav cheloveka v sfere protivodejstviya torgovle lyud'mi v Respublike Kazahstan'. Astana: Komissiya po pravam cheloveka pri Prezidente RK, 2014. 170 s. (Специальный доклад «Актуальные проблемь защиты прав человека в сбере противодействия торговле людьми в Республике Казахстан». Астана: Комиссия по правам человека при Президенте РК, 2014. 170 с.) 
Alimzhan Baurzhanovich Bekmagambetov. Criminological and Criminal Classification of Crimes

Connected with Trafficking in Persons in the Republic of Kazakhstan

20. Spravka o sostoyanii rassledovaniya ugolovnyh del, svyazannyh s torgovlejlyud'mi (st. 116, 125, ch. 3, p.2), 128, 134, 135, 308, 309 UK) za 11 mesyatsev 2016 goda. Astana: MVD RK, 2017. 4 s. (Справка о состоянии расследования уголовных дел, связанных с торговлей мюдьми (ст. 116, 125, ч. 3, п. 2), 128, 134, 135, 308, 309 УК) за 11 месяцев 2016 года. Астана: МВА РК, 2017. 4 c.)

21. Strategicheskij plan General'noj prokuratury Respubliki Kazahstan na 2014-2018 gody. Astana, 2015. (Стратегический план Генеральной прокуратуры Республики Казахстан на 2014-2018 годы. Астана, 2015.)

22. Vedomosti Parlamenta RK. 2013, 15: 78. (Ведомости Парламента РК. 2013, 15: 78.)

23. Vtoroj periodicheskij doklad o vypolnenii Respublikoj Kazahstan Mezhdunarodnogo pakta o grazhdanskih $i$ politicheskih pravah. Utverzhden postanovleniem Pravitel'stva RK ot 03.12.2014 g. No. 1271, Astana, 2014. 34 s. (Второй периодический доклад о выполнении Республикой Казахстан Международного пакта о гражданских и политических правах. УтвержАен постановлением Правитемьства РК от 03.12.2014 г. № 1271. Астана, 2014. 34 с.).

24. Vtoroj periodicheskij natsional'nyj doklad Respubliki Kazahstan v ramkah Universal'nogo periodicheskogo nadzora po pravam cheloveka. Utverzhden postanovleniem Pravitel'stva RK ot 29.09.2014 g. No. 1038. Astana, 2014. 25 s. (Второй периодический начиональный доклад Республики Казахстан в рамках Универсального периодического надзора по правам человека. Утвержден постановлением Правительства РК от 29.09.2014 г. № 1038. Астана, 2014. 25 c.) 